"Those years were the darkest of my professional career." Tony Fauci on HIV - see page 289

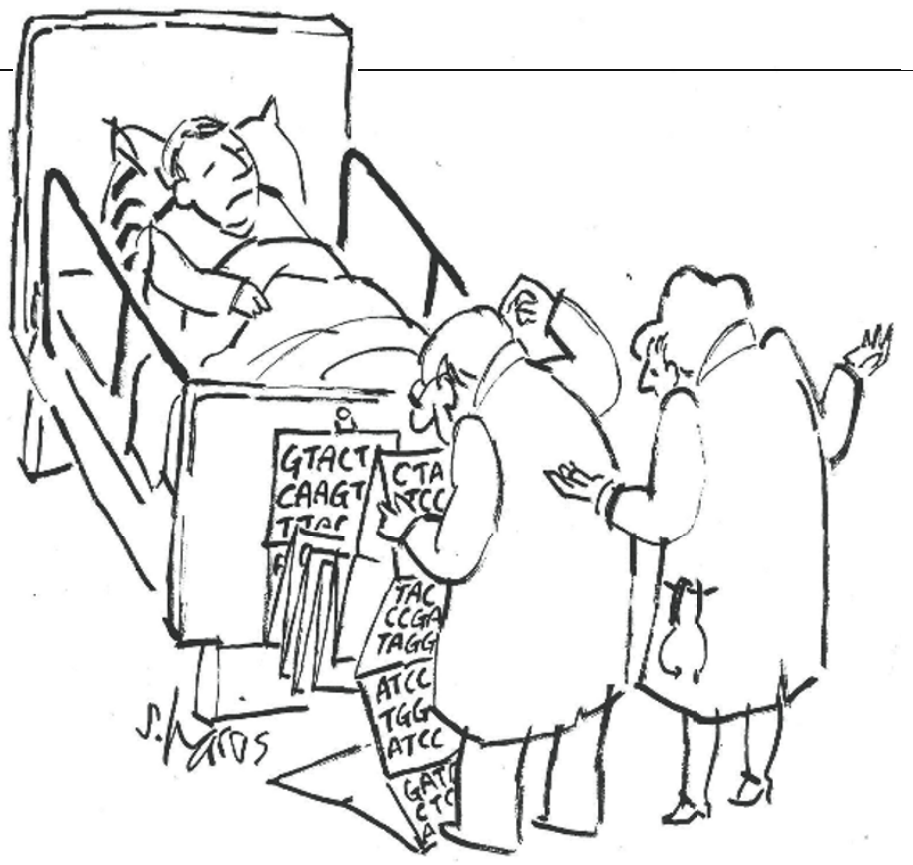

A case of genetic counselling for Dr Watson

SIR - Your recent publication of James Watson's sequenced genome (D. A. Wheeler at al. Nature 452, 872-876; 2008) makes for fascinating reading - that is, for anyone who has enough knowledge of genetics and biology to interpret it. Peel away the single nucleotide polymorphisms (SNPs), the copynumber variations and the indels, and the core message seems, well, empty. As Maynard Olson

\begin{tabular}{|c|c|}
\hline Dr Watson & Lay patient \\
\hline Discovered the structure of the gene & Not exactly sure what a gene is \\
\hline $\begin{array}{l}\text { Thinks the } \$ 1 \text { million cost is a good } \\
\text { deal }\end{array}$ & $\begin{array}{l}\text { Worried about the cost of a } \\
\text { consultation }\end{array}$ \\
\hline Sequence ready in 2 months & Standard test result ready in 2 months \\
\hline Brings in sequence data on a hard drive & Brings in records about sinus infection \\
\hline Can give fully informed consent & Can sign a consent form \\
\hline Released his sequence to the public & Doesn't want mother to know \\
\hline $\begin{array}{l}\text { Chose to have Apo-E sequence } \\
\text { redacted }\end{array}$ & Expects to learn blood type \\
\hline $\begin{array}{l}\text { Understands the limited clinical } \\
\text { relevance }\end{array}$ & Hopes we can fix any broken genes \\
\hline $\begin{array}{l}\text { Shares } 1.68 \text { million SNPs with Craig } \\
\text { Venter }\end{array}$ & Googles SNPs to find out who they are \\
\hline Concerned about not being cloned & Concerned about being cloned \\
\hline
\end{tabular}

\section{The public needs to know social benefits of vaccination}

SIR - You may have been inadvertently off message about vaccination policy in your Editorial 'On message, off target' (Nature 452, 128; 2008) - for what you did not say. Centuries of experience have proved the importance of societies (not doctors, parents or vaccine recipients) in making decisions on whether to vaccinate or not. Having drafted the US national vaccine programme legislation that was passed in 1986, and directed the national vaccine programme in 1993-94, I can say that recent UK experience impressively illustrates the strategic distinction.

After an unexpected rise of pertussis (whooping cough) cases in the 1990s, Britain revamped its system to reward general practitioners for fully immunizing all children on their lists, paying a bonus to those who reached $90 \%$ then, a few years later, $95 \%$. This system did not exclude from the denominator the small number of patients with good medical reasons against receiving vaccine.

Why the societal strategy? No vaccine is fully effective in everyone who receives it. Only 'herd immunity' can protect those in whom a vaccine does not stimulate protective immunity. Population health therefore improves where policies support full coverage of the population. Such policies create a culture in which health authorities educate doctors, parents and patients about the societal goals as well as individual contraindications.

Good immunization policies balance the risks of vaccines against the benefits. All vaccines, usually given to healthy people, pose some small risk. Good medical reasons do occasionally exist for some people to avoid some vaccines. Britain understood this, and designed its policy to avoid incentives for doctors to vaccinate in such situations.
Although vaccination remains voluntary, no programme is based on individual preference. Public education about vaccination is important, particularly to heighten understanding of the basis for all aspects of public policy to maximize protection of human health.

Anthony Robbins Journal of Public Health Policy, 213 West Canton Street, Boston, Massachusetts 02116, USA

\section{Public support never has guaranteed good work}

SIR — Sadly, the implication in your Editorial 'Broken promises' (Nature 452, 503; 2008), that good science depends on good ideas and not good intentions, is unlikely to make much difference to politicians anxious for public favour or to scientists anxious for money.

As you declared more than 15 years ago (Nature 360, 13; 1992), "the increasingly crass politicization of biomedical research looms as something of a menace, for it presupposes first that more money for more scientists is a way to medical salvation, and second that well-meaning groups of citizenactivists and professional lobbyists have a scientifically useful role in deciding where research money should be directed. There is, alas, inadequate evidence to support either proposition." Technology can be bought, but science depends first on ideas and luck, to which the link is more imprecise.

In that News \& Views article, you give four examples where politics threatened to derail science. One of them - five years before the Clinton promise mentioned in the Editorial (it is fascinating just how many breakthroughs are promised "within a decade") - was of the US National Institutes of Health and Food and Drug Administration trying to stop lobbyist-driven testing of an unproven AIDS vaccine.

Neville W. Goodman Bristol, UK 